\title{
Functional Characteristics Of Banking Websites And Customer Loyalty: The Mediating Role Of Online Trust
}

Sarra Berraies, ISIGK, ARBRE, Tunisia

Rached Chtioui, ISIMA, Méthodes Marketing, Tunisia

Karim Ben Yahia, ISBAM, LARIME, Tunisia

\begin{abstract}
The aim of this paper is to analyze the relationship between the websites' functional characteristics, online trust and customer loyalty in banking sector. Our research required the testing of twelve hypotheses with a sample of 286 Tunisian banks' customers. The data were analyzed by structural equations modeling using the AMOS software. The results of our research highlighted the significant and positive effect of the websites' functional characteristics on online trust among customers, which in turn has been proven to be a key driver of their loyalty to their banks. Our study pointed also the mediation role played by online trust between websites' functional characteristics and customer loyalty.
\end{abstract}

Keywords: Website's Characteristics; Online Trust; Loyalty

\section{INTRODUCTION}

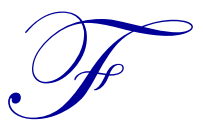

aced with a vast literature consecrated to the concept of loyalty, our study tries to stand out from previous research by focusing on some relationships that are less explored especially in times of a crisis. It focuses on the Tunisian banking sector, which is witnessing deep changes. It was the subject of a government intervention, like many emerging countries until the late 80s (Shaw, 1973), leaving no leeway for Tunisian banks ending up in a financial repression. Faced with this situation, a reform package was initiated to liberalize and modernize the Tunisian financial system and boost competition among banks. After the revolution experienced by Tunisia, this period was marked by real difficulties that have invaded Tunisian banks. In addition, funding concerns arose because the banking system is going through an instability period due to the current circumstances facing the country.

The problem we have chosen to deal with in this study was inspired by a thorough literature review and interviews with executives working in the banking sector and with customers. The aim was to better understand the consequences of the crisis. The results of the content analysis of these interviews show that the last three years have seen a deterioration in the bank-customer relationship, accelerated by the financial crisis. The latter contributed significantly in changing the image of banks causing a crack in the trust relationship that connects the bank to the customer. According to the interviewed officials, in this uncertain climate, trust is at its lowest level. Our qualitative study also revealed the emergence of new behaviors from customers and banks following the crisis. Some customer behavior trends have emerged like no longer keeping liquidity at home, no saving, using less credit cards and showing less trust in banks. The latter have experienced a serious lack of liquidity due to the large sums of money that customers had to withdraw. On the bank side, negligence associated with a degradation of services has led to recent heavy losses in terms of customer portfolio and growth opportunities. Thereby, the impact of the crisis affected not only the institutional and economic actors but also consumer behavior vis-à-vis products and services.

In times of crisis, banks reinforce their conservatism while the customer tends to be more suspicious of their banks. This crisis relationship between the two parties affects the bank-customer dyadic (Kaminsky \& 
Reinhart, 1999). Furthermore, Libaert (2010) stresses that crisis can jeopardize the reputation and stability of an organization.

Thus, banks need to implement reforms and measures which can differentiate themselves from another and in order to win back customers who are becoming increasingly demanding and less trusty. These aspects may include services for customers who bring added value and especially better coverage for customers in search of tranquility.

Faced with this crisis, Tunisian banks went through tough competition. These will need to look for deposits that allow them to respond to customer needs and strengthen their international position. In this perspective, as customer behavior evolves, the bank would have to adapt, anticipate and react to recover from this crisis (Kefi \& Maraghni, 2011). The key words of these banks to improve their image are: trust and loyalty.

To achieve this, banks have begun to speed up in terms of using the internet to promote a more personalized relationship with customers (El Fidha \& Mallek-Tarifa, 2009). All means are implemented to upgrade themselves and this from designing dynamic websites to applications accessible from smartphones.

Based on these theoretical and empirical findings, the idea put forward in this study is that the websites' functional characteristics enhance online trust among customers, which in turn is a determinant of their loyalty to their respective banks. The aim of this study can be reformulated into the following question:

To what extent does online trust mediate the relationship between websites' characteristics and customer loyalty?

After defining the concepts of our study and the relationships between them in the literature review, we present our empirical study and its results.

\subsection{Online Trust}

\section{LITERATURE REVIEW}

Despite an extensive literature on trust, there is a lack of consensus on the definition of this concept. Indeed, trust has been conceptualized in different ways within different disciplines, including sociology, psychology and marketing. In marketing, a review of the literature on this topic suggests that trust is primarily apprehended by two approaches (Chouk \& Perrien; 2003, Morgan \& Hunt, 1994; Robinson, 1996). In line with the first psychological approach and in the same vein of the definition of Chouk \& Perrien (2003) and Robinson (1996), trust is seen as a psychological state that is manifested through a presumption, an expectation or a belief that the other party will have a positive behavior or one that is not at the expense of his/her interests. From a behavioral perspective, trust is defined as confident behavior (Chouk \& Perrien, 2003) or a position of vulnerability which implies a willingness to rely on another party (Mayer et al, 1995).

Many researchers looked at trust as a multidimensional concept that incorporates cognitive and emotional elements (McKnight et al, 2002; Mayer et al, 1995). In this perspective, several dimensions of trust that express the attributes of establishing whether a person can rely on someone else, have been identified in the literature. Morgan \& Hunt (1994) put an emphasis on reliability and integrity as two dimensions of trust. For Young-Ybarra \& Wiersema (1999), trust has three dimensions which are reliability, predictability and faith. Mayer et al. (1995) conceptualize trust through three key dimensions: competence, benevolence, and integrity. In our research, we adopt the definition of trust proposed by Mayer et al. (1995) which is commonly accepted by previous research. This definition embraces trust as positive expectations based on the perception of benevolence, competence and integrity of another party. In this perspective, trust incorporates cognitive, emotional and behavioral components (Chouk \& Perrien, 2003).

At first glance, marketing research addressed trust as an attribute that characterizes relationships between customers and vendors or that link customers to the brand in a traditional context of purchase. Then, this concept has been extended to include the online relationship between customers and sellers. In the context of online marketing, the literature evokes the concept of online trust. Against this background characterized by dehumanization of business relationships, the intrinsic features of the product or service offered online and the risk that the customer 
incurs by disclosing information on a given website makes trust essential. Customers must accept the fact that they are vulnerable to the risk of hacking the website and have to rely on the information provided on the website (Chouk \& Perrien, 2003).

In this research, we focus on the online relationship between customers and their banks. In the same vein, to analyze customers' online trust, it is essential to define the different components of this concept. A thorough review of the literature suggests that many researchers have conceptualized online trust as a customer's positive expectations of some attributes of the merchant or service provider, which are benevolence, integrity and competence (Chouk \& Perrien, 2003; McKnight et al, 2002).

As for the 'competence' dimension, also known as credibility, it refers to a set of expertise and technical skills that the other party has allowing them to perform the requested service and thus meet their commitments (Chouk \& Perrien, 2003; Gurviez \& Korchia, 2002; McKnight et al, 2002). It is about finding the right balance between the partner's competence and the fact of being able to keep their promises (Gurviez \& Korchia, 2002). In this study, competence implies that the bank is able to offer reliable banking services.

Integrity, expresses the sincerity of the other part on their intention to honor their commitments and the promises made to the customer (Aldás-Manzano et al., 2009; McKnight et al., 2002). It relates in particular to the reliability of the information provided on the website as well as the potential of protecting those disclosed by the customer (Chouk \& Perrien, 2003). Integrity approaches the notion of credibility. It implies that the partner will keep his promises. But it is more of a subjective element because it is based on some ethical values to be followed. The difference between credibility and integrity lies in how to design each concept: the first is more objective and highlights the skills of the partner to meet the promised commitments (Gurviez \& Korchia, 2002). However the second is more subjective where the partner meets their commitments in accordance with a code of ethics (Gurviez \& Korchia, 2002). In this research, integrity implies that the bank is honest in respecting its commitments and keeping its promises in relation to information presented on the website.

The third dimension is benevolence. It manifests itself in the trust placed by one towards the other party. In this study, this means that the bank is expected to ensure and defend customers' interests (Chouk \& Perrien, 2003; Gurviez \& Korchia, 2002). It implies that the other party is willing to provide the best service to customers (Akter et al., 2011). In this study, benevolence relates to the fact that the bank uses reasonable efforts to act in the interests of the customer and solve their problems.

Thus, trust is presented as a triplet consisting of three basic dimensions which are competence, benevolence and integrity. In this study, we focus on one of the factors through which banks can influence their customers and gain their trust, in particular the functional characteristics of their websites.

\subsection{Websites' Functional Characteristics As Determinants Of Online Trust}

A lot of researchers showed interest in identifying the determinants of online trust. In this study, we focus on the websites' peculiarities as determinants of customers' online trust towards their banks. In this context, communication and information technology and more specifically Internet offer banks a way to build personalized, interactive and lasting relationships. The website, which is an interface linking customers and banks, is a way to strengthen the interaction between the two parties and to convey a good image of the banks. The idea put forward in this study is that the characteristics of banking websites can play a leading role to win customers' trust and loyalty. In this perspective, the review of the literature has identified five key characteristics related to websites on which banks can act to create a sense of trust with the customer and maintain their loyalty, namely quality of information, ease of use, website design, level of security and respect clients' privacy.

\subsubsection{Quality Of Information}

Several studies consider quality of information presented on the website as a factor that may affect customers' online Trust (Loonam \& O'Loughlin, 2008; Stremtan \& Muntean, 2008). By quality of information, Liang \& Chen (2009) argue that it should meet both quantitative and qualitative criteria namely precision, ease of 
understanding, usefulness, relevance and updating. For Bressolles (2004), level of detail of the information provided on the website should respond to customer needs. Lack of information or not updated information is likely to be a factor of distrust for customers who might misinterpret it (Chouk \& Perrien, 2003). In the context of online shopping, informational deficiencies might be taken by the customer as "the intention of the vendor to mislead him or conceal some flaws in the product" (Chouk, 2009). Conversely, too much information on the website can adversely affect clarity (Chouk \& Perrien, 2003). The right mix of information provided on the website is necessary to meet customer expectations and enhance their trust towards the institution. Therefore, we formulate the following hypothesis:

H1.1: A website's quality of information has a positive effect on online trust.

\subsubsection{Ease Of Use}

Ease of use determines also the quality of a website, the users' satisfaction and their online trust (Bressolles, 2004; Chouk, 2009; Harridge-March, 2006; Shankar et al., 2002). Easily using a website relates to understanding its structure, content clarity, ease of searching and speed in accessing information and how users control what they do (Flavián et al., 2006). For Fogg et al. (2001), a website whose browsing system is considered as simple by the user is more credible than a site whose use is rather complex. Indeed, a good website design ensures customers an experience where they feel confident. In the same vein, Toufaily \& Perrien (2007) point out that ease of use of a bank website is an important factor in building a strong relationship between the bank and its customers. For both authors, "a good website design makes disappear the technological limitations of customers, increasing the skills and expertise of these and reinforces the commitment to a relationship" (Toufaily \& Perrien, 2007). The same idea was highlighted by Gefen et al. (2003) who suggest that ease of use of the website will enhance customer satisfaction and trust towards the institution. However, Rajaobelina (2011) didn't find a significant relationship between ease of use of website and customers' online trust in financial institutions. In light of these controversies, it is appropriate to test the following hypothesis:

H1.2: Perceived ease of use of a website has a positive effect on online trust.

\subsubsection{Website Design}

The website design relates to the visual aesthetics of web pages (Park et al., 2007). Graphics, quality of images and videos, symbols, colors, animation are of a paramount importance for the attractiveness and success of the website (Bressolles, 2004; Cyr, 2008; Moore et al., 2005; Park et al., 2007). Moreover, these can give the user a good impression on the website (Wang \& Emurian, 2005) and may have a significant impact on online satisfaction (Chang \& Wang, 2008; Shankar et al, 2002; Young \& Hyunjoo, 2012).

Quality of design is an important factor for users' trust (Chen \& Dibb, 2010; Cyr, 2008; Schlosser et al. 2006). The appreciation of the website design particularly reports to the user's pleasant experience when browsing through the website (Wang \& Emurian, 2005). The user will have much more trust if the website offers aesthetics and a display that are attractive and suited to their needs (Cyr, 2008). Otherwise, the fact that users do not appreciate the website design will have a negative impact on the frequency of their visits to the website (Cunliffe, 2000). In ecommerce, customers tend to think that the company that has invested in the design of their website is likely to process electronic transactions successfully (Schlosser et al., 2006). Rajaobelina (2011) showed empirically that website's design positively influences customers' online trust towards financial institutions. In light of the above, we argue that a good design creates a friendly virtual environment that has the effect of boosting customers' online trust. Thus, we propose the following hypothesis:

H1.3: Appreciating a website design positively affects online trust.

\subsubsection{Security / Respect Of Privacy}

Faced with illegal intrusion and piracy risks, several studies have shown that websites security and privacy respect significantly influence customers' online trust (Bart et al, 2005; Chen \& Barnes, 2007; Chouk, 2009). 
Security refers to all the mechanisms used to protect users against "the risk of fraud and financial loss" (Bressolles \& Nantel, 2007). The concept of privacy respect relates to the "protection of personal data and refraining from selling or sharing them with other websites" (Bressolles \& Nantel, 2007). Indeed, the intangible aspect of websites and thus the absence of interpersonal online contact make these elements considerably important. Securing a given website will encourage and motivate the customer to use it and to maintain a sustainable online relationship (Chen, 2006).

Many authors such as Chen et al. (2008) and Shankar et al. (2002) emphasized that the security of a website and respect of privacy are key determinants of online trust. However, lack of protection of personal information or security represents an obstacle to the use of a website and the realization of online transactions (Chen et al., 2008). Rajaobelina (2011) concluded that perceived security / respect of privacy determines customers' online trust towards financial institutions. Thus, we propose the following hypothesis:

H1.4: 'Perceived security / respect of privacy' has a positive effect on online trust.

\subsubsection{Online Trust As A Determinant Of Customer Loyalty}

Despite a rich literature dealing with the concept of loyalty, it is noticeable that there is no consensus on its definition. More than 300 definitions of behavioral loyalty have been identified by Jacoby \& Chestnut (1978). Among the identified definitions, loyalty is expressed through the repetition of the act of purchase (Cunningham, 1956). Indeed, this conative indicator prevails while the cognitive is ignored. Only the repetition of the act of purchase reflects customer loyalty. This definition omits several aspects that predict buyer behavior and motivations. For Oliver (1999), the importance of customer loyalty lies in the customer's strong commitment to the act of repurchasing and re-attending the future service or product despite the tempting offers presented by the competitors. In line with Oliver (1997), we define loyalty as "a deep commitment expressed by the consumer to buy again the product or the service they prefer, consistently in the future despite influences of marketing and situational effects that may induce a change of brand ". For their part, Jacoby \& Kyner (1973) define loyalty as "an non-random behavioral response expressed through time by a decision unit on one or more brands taken in a set, in terms of a psychological decision process". From these two definitions, we outline the different aspects of loyalty, already proposed by Jacoby \& Chestnut (1978):

- $\quad$ At the cognitive level, the consumer has information indicating that the chosen brand is far superior than competitors'.

- $\quad$ At the emotional level, consumer should clearly prefer this brand.

- $\quad$ At the conative level, consumer should has the intention to re-purchase.

Furthermore, according to Oliver (1999), loyalty proceeds in four stages: three before re-purchase and one after. Cognitive loyalty appears after the informational assessment process of other brands by the consumer. Then, an emotional dimension predominates and the consumer feels some attachment. Conative loyalty emerges next when a consumer expresses an intention to repurchase the product. The last stage is when there is a succession of the purchase. In this case, Oliver (1999) speaks of behavioral loyalty in the sense that consumers are still loyal to the brand and insensitive to various offers from other competing brands. According to this categorization, loyalty is exclusive to one brand when in reality and under some circumstances, consumers are likely to switch brands temporarily. In this study, we understand loyalty as a concept consisting of three aspects, namely emotional, cognitive and conative (Jacoby \& Chestnut, 1978; Oliver, 1999).

In fact, customer loyalty and its determinants are at the heart of the concerns of any business. In this study, we focus on one of these determinants, namely online trust.

Several studies have focused on understanding the relationship between trust and loyalty (Kassim \& Abdullah, 2010; Eastlick et al., 2006). Trust is an essential factor in maintaining a lasting relationship in the business world and in the financial industry in particular. As pointed out by Reichheld \& Schefter (2000), "to earn customer loyalty, we must first gain their trust." Indeed, establishing an online trust between customer and company is a prerequisite for loyalty (Sultan et al., 2003). Eastlick et al. (2006) advocated that there is a positive relationship between online trust and the cognitive, affective and conative dimensions of loyalty. Moreover, Rajaobelina (2011) found that online trust positively affects these three aspects of customer loyalty to their financial institutions. 
Building a trust relationship through their websites is particularly important for companies facing different online exchange risks in order to build a lasting relationship with their customers (Anderson \& Srinivasan, 2003). Consequently, we formulate the following hypothesis:

H2: Online Trust has a positive effect on customer loyalty.

\subsection{Online Trust As A Mediating Variable Between Websites' Functional Characteristics And Customer Loyalty}

The four characteristics of websites examined have been proven to be determinants of online trust, which in turn is a key factor of customer loyalty. Online trust could therefore be a mediating variable that could explain the indirect link between the functional characteristics of websites and customer loyalty. We then formulate these hypotheses:

H 3.1: Online Trust mediates the relationship between websites' quality of information and customer loyalty.

H 3.2: Online Trust mediates the relationship between websites' ease of use and customer loyalty.

H 3.3: Online Trust mediates the relationship between the appreciation of websites' design and customer loyalty.

H 3.4: Online Trust mediates the relationship between security / respect for privacy in websites and customer loyalty.

\subsection{The research model}

In light of the above analysis, we have developed the following model that synthesizes the relationships between the research variables.

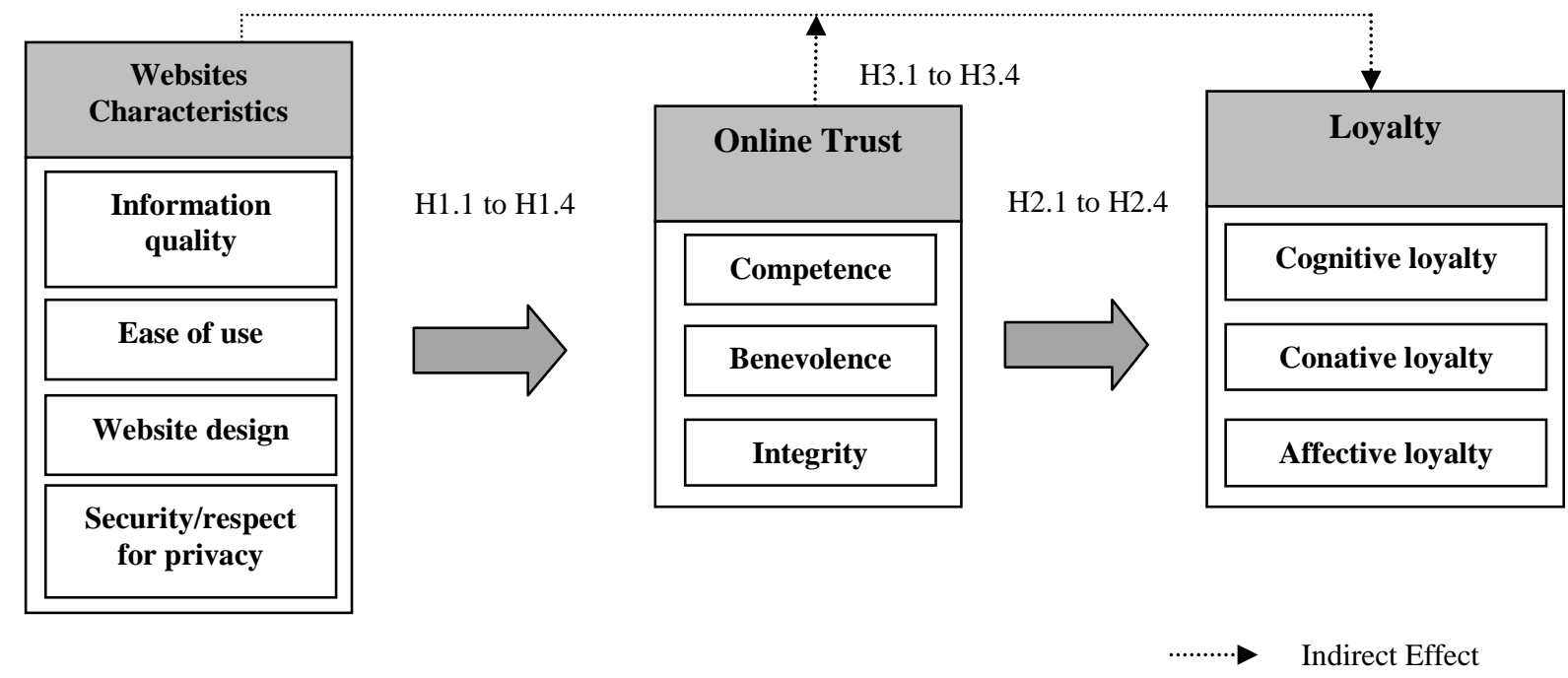

Figure 1. Research Model

\section{THE EMPIRICAL STUDY}

To test our research hypotheses, we opted for a quantitative data collection method. Data was collected using a questionnaire administered to bank customers, particularly those who have access to their bank accounts via Internet. We ended up with a convenience sample of 286 bank customers who completed the questionnaire. Sample size is particularly suitable to analyze data using structural equation modeling. 


\subsection{Measures, reliability and validity of constructs}

Websites' Characteristics were measured using the scales of Bressolles (2006), Chen \& Barnes (2007) and the one adapted by Rajaobelina (2011) particularly useful to our research as it focuses on the banking websites' characteristics. Online trust was assessed as a three-dimensional construct consisting of competence, benevolence and integrity and measured by the scales of Chouk \& Perrien (2005), Hess (1995) and Pavlou (2003). Finally, the scales of McMullan \& Gilmore (2003) and Oliver (1999) were used to measure loyalty. We use a 5-point Likerttype scale ranging from $1=$ strongly disagree to $5=$ strongly agree.

A principal component analysis with a varimax rotation using SPSS 18.0 was performed to test constructs' dimensionality. Items with scores whose factorial weightsare below 0.5 have been removed. Then, Cronbach's alpha was used to test constructs' reliability and was considered suitable to the threshold of 0.7 (Nunnally, 1978). Given the results, the lowest alpha is 0.818. Moreover, a confirmatory factor analysis was performed using AMOS 18.0. Constructs' reliability was reconfirmed. Indeed, the results (Table 1) indicate that Jöreskog's Rhôs vary from 0.701 to 0.962 and are well above the threshold of 0.7 .

Table 1. Constructs' Reliability

\begin{tabular}{lccc}
\hline \multicolumn{1}{c}{ Constructs } & Number Of Items & Cronbach Alpha & Jöreskog's Rhôs \\
\hline Information quality & 3 & 0.934 & 0.903 \\
Ease of use & 3 & 0.868 & 0.849 \\
Website design & 3 & 0.820 & 0.887 \\
Security/ respect for privacy & 3 & 0.877 & 0.889 \\
Competence & 4 & 0.935 & 0.932 \\
Integrity & 3 & 0.840 & 0.906 \\
Benevolence & 3 & 0.918 & 0.921 \\
Cognitive loyalty & 3 & 0.888 & 0.910 \\
Affective loyalty & 4 & 0.818 & 0.799 \\
Conative loyalty & 3 & 0.949 & 0.962 \\
\hline
\end{tabular}

Next, convergent validity of the constructs was confirmed as the values of the average variance extracted (AVE) range between 0.521 and 0.919 and thus are greater than 0.5 as recommended by Fornell \& Larcker (1981). Constructs' discriminant validity was confirmed through the method advocated by Fornell \& Larcker (1981) by ensuring that the AVE of each construct (on the diagonal of Table 2) is higher than the squared correlations between each pair of constructs.

Table 2. Convergent And Discriminant Validity Of Constructs

\begin{tabular}{|c|c|c|c|c|c|c|c|c|c|c|c|}
\hline & Constructs & 1 & 2 & 3 & 4 & 5 & 6 & 7 & 8 & 9 & 10 \\
\hline 1 & Information Quality & 0.757 & & & & & & & & & \\
\hline 2 & Ease of use & 0.041 & 0.655 & & & & & & & & \\
\hline 3 & Website design & 0.078 & 0.032 & 0.728 & & & & & & & \\
\hline 4 & Security/ privacy & 0.023 & 0.057 & 0.065 & 0.726 & & & & & & \\
\hline 5 & Competence & 0.129 & 0.018 & 0.079 & 0.049 & 0.821 & & & & & \\
\hline 6 & Bienveillance & 0.033 & 0.027 & 0.028 & 0.003 & 0.341 & 0.709 & & & & \\
\hline 7 & Integrity & 0.054 & 0.483 & 0.068 & 0.097 & 0.135 & 0.256 & 0.812 & & & \\
\hline 8 & Cognitive loyalty & 0.063 & 0.145 & 0.002 & 0.026 & 0.033 & 0.019 & 0.261 & 0.772 & & \\
\hline 9 & Affective loyalty & 0.036 & 0.067 & 0.011 & 0.013 & 0.529 & 0.396 & 0.063 & 0.064 & 0.521 & \\
\hline 10 & Conative loyalty & 0.021 & 0.349 & 0.049 & 0.089 & 0.085 & 0.017 & 0.425 & 0.339 & 0.070 & 0.919 \\
\hline
\end{tabular}

We examined also the fit indices of the variables' measurement models and concluded that they meet the proposed thresholds. In line with the theoretical findings, we tested a second-order models for online trust and loyalty, which showed evidence of satisfactory fit. Results indicate that these models fit the data better than the first order models. 


\subsection{Results}

The research model was assessed using a structural equation analysis using maximum likelihood method in AMOS 18.0 software. The global model's fit indices were first examined and compared against the thresholds recommended by Chin \& Todd (1995) and $\mathrm{Hu} \&$ Bentler (1999). The Chi-square value to degrees of freedom is 2.167 and is below the threshold of 3. The RMSEA index is 0.062 , lower than the recommended threshold of 0.08 . CFI (0.965) and NFI (0.943) are also satisfactory (above 0.9). Results indicate the good fit of the empirical model to the conceptual model.

Regarding hypothesis testing, it is clear that quality of information has a positive and significant relationship with customers' online trust to their banks $(\beta=0.266, \mathrm{p}<0.001)$. Then, the results revealed that ease of use significantly affects online trust $(\beta=0.187, \mathrm{p}<0.001)$. The appreciation of website design, in turn, positively relates to online trust $(\beta=0.260, \mathrm{p}<0.001)$. Finally, security / respect for privacy emerged as the website feature that has the most effect on online trust $(\beta=0.738, \mathrm{p}<0.001)$. Hypotheses 1.1 to 1.4 are confirmed. Moreover, the results highlighted that online trust has a positive and significant effect on customer loyalty $(\beta=0.720, p<0.001)$ and allows us to confirm hypothesis 2 .

As for the squared multiple correlation (SMC), it is 0.718 when regressing online trust on websites' characteristics and 0.843 when regressing loyalty on both websites' characteristics and online trust.

Table 3. Test Of Hypothesis

\begin{tabular}{clllll}
\hline Hypothesis & \multicolumn{1}{c}{ Independent Variable } & Dependent Variable & B & C.R. & P \\
\hline H1.1 & Information Quality & Online trust & 0.266 & 3.428 & $* * *$ \\
H1.2 & Ease of use & Online trust & 0.187 & 4.566 & $* * *$ \\
H1.3 & Website design & Online trust & 0.260 & 4.365 & $* * *$ \\
H1.4 & Security/ privacy & Online trust & 0.738 & 6.516 & $* * *$ \\
H2 & Online trust & Loyalty & 0.720 & 6.428 & $* * *$ \\
\hline
\end{tabular}

$\beta$ : standardized regression coefficient, C.R. : critical ratio, *** : P-value $(\mathrm{P})<0,001$

From the results, the characteristics of websites are direct factors of online trust, which is a direct factor of customer loyalty. Thus, they are indirect factors of online loyalty. This suggests that online trust could mediate the relationship between the characteristics of websites and customer loyalty. This mediation hypothesis was tested using the four-step method recommended by Baron \& Kenny (1986). According to this method, a first model is tested in which the independent variable (X) must have a significant effect on the dependent variable (Y). Then, $\mathrm{X}$ must have a significant impact on the mediating variable (M). Moreover, M must significantly influence $\mathrm{Y}$ when the effect of $\mathrm{X}$ on $\mathrm{Y}$ is controlled. At this level, if the influence of $\mathrm{X}$ on $\mathrm{Y}$ by introducing $\mathrm{M}$ disappears, mediation is complete. If it is lower but still significant, there is partial mediation.

In line with this approach, we tested a model examining the direct links between the independent variables (the characteristics of websites) and the dependent variable (loyalty). This model explains $57 \%$ of the variance of loyalty. The results revealed that appreciation of website design $(\beta=0.422, p<0.001)$, ease of use $(\beta=0.352$, $p$ $<0.001)$, quality of information $(\beta=0.496, \mathrm{p}<0.001)$ and perceived security / respect for privacy $(\beta=0.796, \mathrm{p}$ $<0.001)$ have a significant impact on loyalty. The first condition of mediation recommended by Baron \& Kenny (1986) is satisfied for these variables. Moreover, as we mentioned, the results confirmed there are significant and positive relationships between the characteristics of the website and online trust (Table 3). Henceforth, the second condition of mediation is also validated. The results confirmed also that online trust determines loyalty in the model containing all the variables. The third condition of mediation is also validated. At this level, we can confirm that online trust is a variable mediating the relationship between the four characteristics of websites and customer loyalty.

When Online Trust is introduced in the model, the relationship between quality of information $(\mathrm{CR}=4.279$ and $\mathrm{p}<0.001)$, ease of use $(\mathrm{CR}=2.894$ and $\mathrm{p}<0.01)$, appreciation of design $(\mathrm{CR}=3.257 \mathrm{p}<0.001)$, and 'security / respect of privacy' $(\mathrm{CR}=3.839$ and $\mathrm{p}<0.001)$ and loyalty decreased compared to the first tested model but remained significant. Online Trust has not therefore fully transmitted the impact of these websites features to loyalty. There is therefore partial mediation. The Sobel test has enabled us to further examine the significance of the mediating 
effects. This test is significant for quality of information $(Z=2.476, p<0.05)$, ease of use $(Z=2.017, p<0.05)$, appreciation of design $(Z=2.064, p<0.05)$ and 'security / respect of privacy' $(Z=2.584, p<0.05)$. Accordingly, hypotheses 3.1 to 3.4 are confirmed.

\subsection{Discussion}

The results of our empirical study have allowed us to highlight the important role played by certain characteristics of banking websites in enhancing customers' online trust and their loyalty.

The variable 'respect for privacy and perceived security' of Tunisian banks websites appears to be the most important determinant of customers' online trust. This result supports the work of Chen et al. (2008), Shankar et al. (2002) and in particular Rajaobelina (2011) who has empirically tested this link in the context of the online relationship between financial institutions and their customers. Thus, customers would be more likely to use online services of banks and to share their personal information if they perceive that websites are secure enough. Moreover, the establishment of an online trust relationship between customers and their banks reports to minimizing the risk associated with surfing the internet, including financial loss or identity theft risks. Under the impact of the economic crisis, the issue of securing websites and protecting customer information is very crucial to establish a trust-full relationship with them. Indeed, in a context of crisis, customers are more wary about the disclosure of their personal data and about carrying out online transactions.

Quality of information supplied on the banks' website is also a factor determining customers'online trust. This is consistent with the findings of Rajaobelina (2011), Loonam \& O'Loughlin (2008) and Liang \& Chen (2009). These interfaces can offer customers a range of detailed information on their personal account or provide them personalized and differentiated services (Notebaert et al, 2008) including: Request for check books, bank cards or credits, making appointments... In times of crisis, known for increased uncertainty, customers pay special attention to quality of information. To win their trust, banks are so called to reassure them by providing relevant, detailed and regularly updated information to help them make the right decisions (Ahn et al., 2007).

The results also indicate a significant relationship between appreciation of website design and online trust. This is consistent with the work of Bart et al. (2005), Cyr (2008) \& Rajaobelina (2011). A website characterized by a high quality design helps provide a friendly virtual environment and gain Tunisian customers' online trust. Furthermore, the relationship between ease of use and online trust is also statistically significant. This result goes against the findings of Rajaobelina (2011) who found no significant relationship between ease of use and customers' online trust in financial institutions. However, it is consistent with the work of Toufaily \& Perrien (2007) and Gefen et al. (2003).

The findings also highlighted that online trust is a way for banks to retain customers (Eastlick et al, 2006; Rajaobelina, 2011). Moreover, this study has enabled us to identify the partial mediating role that online trust plays in the relationship between the functional characteristics of websites and loyalty. Thus, to gain trust of their customers and their loyalty, Tunisian banks are expected to take advantage of their websites as tools to foster their relationships with their customers. Indeed, the website is a way to build customized, durable and trusting relationships with them.

\section{CONCLUSION}

There are several studies that showed interest in loyalty to companies and specifically financial institutions. These studies highlight the important role of online trust as a determinant of customer loyalty. In this study, the question we asked was: loyalty?

To what extent does online trust mediate the relationship between websites' characteristics and customer

To address this issue, two objectives were set. The first is to provide some answers to the raised question and the second is to make available to managers of banks a scientific tool for describing the variables that influence the most online trust and customer loyalty. 
A preliminary qualitative study was conducted whose purpose is to identify new customer behaviors towards degradation of bank services during a crisis. Following this study, it seems clear that banks have responded to the crisis by modernizing their websites in order to regain their customers' trust and loyalty.

The conducted literature review has linked first the main website characteristics related to the online trust and second explained the online trust-loyalty relationship. This literature review also allowed us to identify some variables that act directly or indirectly on customer loyalty to banks. The list of these variables is not exhaustive within our study context as the concept of loyalty is not limited only to website characteristics.

A quantitative survey of 286 bank customers was conducted and allowed us to highlight many relationships:

- $\quad$ Perceived security / respect for privacy, appreciation of design, ease of use and quality of information of a website have a positive effect on online trust.

- $\quad$ Online Trust has a positive effect on customer loyalty.

- $\quad$ Online trust has a mediating role between the functional characteristics of websites and customer loyalty.

The results of this research also suggest that banks should focus on both operational and informational components of website as well as aesthetic component. Moreover, it is clear that the variable 'website security and respect of privacy' seems to be the most important factor that affects trust.

Methodologically, this study combined two approaches: a qualitative and a quantitative approach. The first was to explore the major effects of the crisis on the banking sector and the second was to test the relationships between the variables of our conceptual model.

This study has focused on websites' inherent variables. However, the main limitation was in not taking into consideration other factors of online trust, which include seller features, customer relationship with the bank features and customer intrinsic features. It would be interesting to incorporate these features in future research. On a managerial level, a dyadic study on customers and bank officials seems to be an interesting perspective to compare the results. It would also be useful to replicate this study in different sectors other than banking.

\section{AUTHOR INFORMATION}

Sarra Berraies is Doctor in Management (Higher Institute of Management of Tunis). She is an assistant professor and teaches management, marketing, accounting and finance in the Higher Institute of Management and Computer Science of Kairouan. Her research interests include knowledge management, learning, innovation, trust, emarketing, creation value, performance and governance. She published extensively in academic journals and participated in several international conferences such as International Business Information Management Association (IBIMA), International Conference on Business research and International Marketing Trends Conference. E-mail: sarraberraies610@yahoo.fr

Rached Chtioui is Doctor in Marketing (Higher School of Commerce of Tunis). He is an assistant professor and teaches both management and marketing in ISIMA. His research focuses on the distribution channels and consumers behaviors. Mr Chtioui published his research work in academic journals and participated in several international conferences. He was also a coordinator of numerous international conferences. E-mail: rached.chtioui @ hotmail.fr

Karim Ben Yahia is Ph.D student in marketing at the "Higher Institute of Management", Tunisia. He is an Assistant Professor and teaches both management and marketing in the ISBAM. His research focuses on the cultural congruency in advertising. Mr Ben Yahia published his research work in academic journals, and participated in several international conferences such as Annual Conference European Marketing Academy (EMAC), International Research Days on Marketing Communications and International Marketing Trends Conference. E-mail: karim_b_yahia@yahoo.fr 


\section{REFERENCES}

Akter, S., D’Ambra, J. \& Ray, P. (2011). An Evaluation of PLS based Complex Models: The Roles of Power Analysis, Predictive Relevance and GoF Index. 17th Americas Conference on Information Systems in Detroit.

Ahn, T., Ryu, S. \& Han, I. (2007). The impact of Web quality and playfulness on user acceptance of online retailing. Information and Management, 44(3), 263-275.

Aldás-Manzano, J., Lassala-Navarré, C., Ruiz-Mafé, C. \& Sanz-Blas, S. (2008). The role of consumer innovativeness and perceived risk in online banking usage. International Journal of Bank Marketing, 27(1), 53-75.

Anderson, R.E. \& Srinivason, S.S. (2003). E-satisfaction and e-loyalty: a contingency framework. Psychology and Marketing, 20 (2), 123-138.

Baron, R.M. \& Kenny, D.A. (1986). The Moderator-Mediator Variable Distinction in Social Psychological Research: Conceptual, Strategic, and Statistical Considerations. Journal of Penality and Social Psychology. 51(6), 1173-1182.

Bart, Y., Venkatesh, S., Fareena, S. \& Urban, G.L. (2005). Are the drivers and role of online trust the same for ail Websites and consumers? A large-scale exploratory empirical study. Journal of Marketing, 69 (4), 133152.

Bressolles, G. (2004). Proposition d'une échelle de mesure multidimensionnelle de la qualité de service des sites Web commerciaux: Netqual. $20^{\text {th }}$ International Congress of French Association of Marketing in Saint Malo.

Bressolles, G. (2006). La qualité de service électronique : NetQual, Proposition d'une échelle de mesure appliquée aux sites marchands et effets modérateurs. Recherche et Applications en Marketing, 21 (3), 19-45.

Bressolles, G. \& Nantel, J. (2007). Vers une typologie des sites web destinés aux Consommateurs. Revue Française du Marketing, 213 (3/5), 41-56.

Chen, Y-H., \& Barnes, S. (2007). Initial trust and online buyer behavior. Industrial Management \& Data Systems, 107 (1), 21-36.

Chen, J. \& Dibb, S. (2010). Consumer trust in the online retail context: Exploring the antecedents and consequences. Psychology and Marketing, 27 (4), 323-346.

Chen, E. (2006). Identifying significant factors influencing consumer trust in an online travel site. Information Technology \& Tourism, 8 (3), 197-214.

Chin, W.W. \& Todd, P.A. (1995). On the Use, Usefulness, and Ease of Use of Structural Equation Modeling in MIS Research: A Note of Caution. MIS Quarterly. 19 (2), 237-246.

Chouk, I. (2009). Achat sur internet : comment susciter la confiance?. L'Harmattan.

Chouk, I. \& Perrien, J. (2003). Les déterminants de la confiance du consommateur lors d'un achat sur un site marchand : proposition d'un cadre conceptuel préliminaire. 19th International Congress of Frensh Association of Marketing in Tunisia.

Chouk, L. \& Perrien, J. (2005). La confiance du consommateur vis-à-vis d'un marchand Internet: Proposition d'une échelle de mesure. Revue Française du Marketing, 205, 5-20.

Cunliffe, D. (2000). Developing usable Websites: A review and model. Internet Research, 10 (4), 295-307.

Cunningham, R.M. (1956). Brand loyalty-what, where, how much. Harvard Business Review, 34, (1), 116-128.

Cyr, D. (2008). Modeling Website design across cultures: Relationships to trust, satisfaction, and e-loyalty. Journal of Management Information Systems, 24 (4), 47-72.

Eastlick, M.A., Lotz, S.L., \& Warrington, P. (2006). Understanding online B-to-C relationships: An integrated model of privacy concerns, trust and commitment. Journal of Business Research, 59 (8), 877-886.

El Fidha, C. \& Mallek-Tarifa, A. (2009). TIC et culture: cas du secteur bancaire. Management \& Avenir, 2009/1 (21), 9-9.

Flavian, C., Miguel, G. \& Raquel, G. (2006). The role played by perceived usability, satisfaction and consumer trust on website loyalty. Information \& Management, 43 (1), 1-14.

Fogg, B.L., Marshall, J., Laraki, O., Osipovich, A., Varma, C., Fang, N., Paul, J., Rangnekar, A., Shon, J., Swani, P. \& Treinen, M. (2001). What makes Websites credible?: A Report on a Large Quantitative Study. SIGCHI Conference (Special Interest Group on Computer Human Interaction) in Seattle, USA, 61-68.

Fornell, C. \& Larcker, D.F. (1981). Evaluating structural equation models with unobservable variables and measurement error. Journal of Marketing Research, 18 (1), 39-50.

Gefen, D., Karahanna, E. \& Straub, D.W. (2003). Trust and TAM in Online Shopping: An Integrated Model. MIS 
Quarterly, 27 (1), 51-90.

Gurviez, P. \& Korchia, M. (2002). Proposition d'une échelle multidimensionnelle de la confiance dans la marque. Recherche et Applications en Marketing, 17 (3), 41-58.

Hamadi, C. (2008). La Qualité Perçue de l'Internet Bancaire: Proposition d'une échelle de Mesure. ${ }^{\text {st }}$ International Congress on Management of trust and Internet, in Aix-en Provence, France.

Harridge-March, S. (2006). Can the building of trust overcome consumer perceived risk ontine?. Marketing Intelligence \& Planning, 24 (7), 746-761.

Hess, J. (1995). Construction and Assessment of a Scale to Measure Consumer Trust, AMA Educators Conference, Enhancing Knowledge Development in Marketing, eds B.B. Stern et G.M. Zinkhan, 6, 20-25.

Hu, L.T. \& Bentler, P.M. (1999). Cutoff Criteria for Fit Indexes in Covariance Structure Analysis: Conventional Criteria versus New Alternatives. Structural Equation Modeling. 6(1), 1-55.

Jacoby, J. \& Kyner, D.B. (1973). Brand loyalty vs. repeat purchasing behavior. Journal of Marketing Research, 10 (1), $1-9$.

Jacoby, J. \& Chestnut, R.W. (1978). Brand Loyalty: measurement and management. Wiley: New York.

Kaminsky, G. \& Reinhart, C. (1999). The Twin Crises: The Causes of Banking and Balance of Payments Problems. American Economic Review, 89 (3), 473- 500.

Kassim, N. \& Abdullah, N.A. (2010). The effect of perceived service quality dimensions on customer satisfaction, trust, and loyalty in e-commerce settings: A cross cultural analysis. Asia Pacific Journal of Marketing and Logistics, 22(3), 351-371.

Kefi, M.K. \& Maraghni, H., (2011). Respect des normes prudentielles et solvabilité des banques commerciales : étude empirique des banques tunisiennes. Management \& Avenir, 8 (48), 382-403.

Liang, C.J. \& Chen, H.J. (2009). A study of the impacts of Website quality on customer relationship performance. Total Quality Management \& Business Excellence, 20 (9), 971-988.

Libaert, T. (2005). La communication de crise. Paris : Dunod.

Loonam, M. \& O'Loughlin, D. (2008). Exploring e-service quality: A study of Irish online banking. Marketing Intelligence \& Planning, 26 (7), 759-780.

Mayer, R.C., Davis, J. \& Schoorman, D. (1995). An integrative model of organizational trust. Academy of Management Review, 20 (3), 709-734.

McKnight, D.H., Choudhury, V. \& Kacmar, C. (2002). Developing and validating trust measures for e-commerce: An integrative typology. Information Systems Research, 13(3), 334-359.

McMullan, R. \& Gilmore, A. (2003). The conceptual development of customer loyalty measurement a proposed scale. Journal of Targeting, Measurement and Analysis for Marketing, 11(3), 230-243.

Morgan, R. \& Hunt, S. (1994). The commitment-trust theory of relationship marketing. Journal of Marketing, 58 (3), 20-38.

Moore, R., Stammerjohan, C. \& Coulter, R. (2005). Banner advertiser-website context congruity and colour effects on attention and attitudes. Journal of Advertising, 34 (2), 71-84.

Notebaert, J.F., Assadi, D., Attuel-Mendes, L. (2008). L'individualisation de la relation sur Internet : une analyse comparative du service client en ligne des banques françaises. Management \& Avenir, 16, 174-190.

Nunnally, J.C. (1978). Psychometrie theory. New York: McGraw-Hill.

Oliver, R.L. (1997). Satisfaction: a behavioral perspective on the consumer. New York: McGraw Hill.

Oliver, R.L. (1999). Whence Customer Loyalty. Journal of Marketing, 63 (Special Issue), 33-44.

Park, A.Y., Gretzel, U. et Sirakaya-Turk, E. (2007). Measuring Web Site Quality for Online Travel Agencies. Journal of travel and tourism marketing, 23 (1), 15-30.

Pavlou, P. (2003). Consumer acceptance of electronic commerce: Integrating trust and risk in the technology acceptance model. International Journal of Electronic Commerce, 7 (3), 101-134.

Rajaobelina, L. (2011). Les antécédents et les conséquences de la confiance en ligne : le cas du secteur financier, Doctoral dissertation, University of Québec, Montréal.

Reichheld, F.F. \& Schefter, P. (2000). E-Loyalty: Your Secret Weapon on the Web. Harvard Business Review, 78 (4), 105-113.

Robinson, S.L. (1996). Trust and breach of the psychological contract. Administrative Science Quarterly, 41(4), 574-599.

Schlosser, A.E., White, T.B. \& Lloyd, S.M. (2006). Converting web site visitors into buyers: how web site investment increases consumer trusting beliefs and online purchase intentions. Journal of Marketing. 70 (2), 133-148. 
Shankar, V., Urban, G.L. \& Sultan, F. (2002). On-line trust: A stakeholder perspective, concepts, implications, and future directions. Journal of Strategic Information Systems, 2 (3/4), 325-244.

Shaw, E.S., (1973). Financial Deepening in Economic Development. Oxford University Press.

Stremtan, F. \& Muntean, A. (2008). Measuring quality of the services provided by the commercial Websites. Annales Universitatis Apulensis Series Oeconomica, 2 (10), 53-56.

Sultan, B., Janicot, S. et Diedhiou, A. (2003), The West African monsoon dynamics, Part I : Documentation of intraseasonal variability, Journal of Climate, 16, 3389-3406.

Toufaily, E. \& Perrien, J. (2007). Typologie des déterminants de la relation banque - client dans un contexte du commerce électronique. 14th International Conference of strategic Management in Montréal.

Wang, Y.D. \& Emurian, H.H. (2005). An overview of online trust: concepts, elements and implications. Computers in Human Behavior, 21 (1), 105-125.

Young, H. \& Hyunjoo, I. (2012). Role of website design quality in satisfaction and word of mouth generation. Journal of Service Management, 23 (1), 79-96.

Young-Ybarra, C. \& Wiersema, M. (1999). Strategic Flexibility in Information Technology Alliances: The Influence of Transaction Cost Economics and Social Exchange Theory. Organization Science, 10(4), 439459. 